\title{
Effect of sucrose and plant growth regulators on callogenesis and preliminary secondary metabolic of different explant Myrmecodia tuberosa
}

\author{
YANTI PUSPITA SARI ${ }^{1, \bullet}$, EKO KUSUMAWATI ${ }^{1}$, CHAIRUL SALEH ${ }^{2}$, WAWAN KUSTIAWAN ${ }^{3}$, \\ SUKARTINGSIH ${ }^{3}$ \\ ${ }^{1}$ Department of Biology, Faculty of Mathematics and Natural Sciences, Mulawarman University. Jl. Barong Tongkok No. 4, Kampus Gn. Kelua, \\ Samarinda, 75119, Kalimantan Timur, Indonesia. Tel.: +62-541 747974, Fax: +62-541-747974, ”email: ypsman2002@yahoo.com \\ ${ }^{2}$ Department of Chemistry, Faculty of Mathematics and Natural Sciences, Mulawarman University. Jl. Barong Tongkok No. 4, Kampus Gn. Kelua, \\ Samarinda, 75119, Kalimantan Timur, Indonesia \\ ${ }^{3}$ Faculty of Forestry, Mulawarman University. Samarinda 75119, East Kalimantan, Indonesia
}

Manuscript received: 24 July 2018. Revision accepted: 24 August 2018.

\begin{abstract}
Sari YP, Kusumawati E, Saleh C, Kustiawan W, Sukartingsih. 2018. Effect of sucrose on callogenesis and preliminary secondary metabolic of different explant (Myrmecodia tuberosa). Nusantara Bioscience 10: 183-192. Myrmecodia tuberosa Jack is a medicinal plant that contains bioactive compounds, such as flavonoids, tannins, tocopherols, phenols, and an abundance of minerals, that are useful as antioxidants. With the constant increases in popularity of the medicinal plant, the $M$. tuberosa is threatened by extinction if over-exploitation continues. Thus, the effort to conserve this plant is vital. Tissue culture is an alternative method to conserve and produce active compounds that are similar to those of the native ant nest plant with callus. The addition of certain compounds such as sucrose can affect the secondary metabolite content through in vitro plant or callus. The aim of this research was to find the explant sources (cotyledon, stem, tuber, and root), determine the best growth regulator to produce the callus, and evaluate the optimum sucrose concentration to enhance secondary metabolite production of the callus. The results showed that callus was obtained from all explant sources and all growth regulators. The best callus that was marked by a friable green and yellowish green callus was provided by cotyledon with the growth regulator of $2 \mathrm{mg} \cdot \mathrm{L}^{-1}$ of 2.4-dichlorophenoxyacetic acid (2.4-D) and $2 \mathrm{mg} \cdot \mathrm{L}^{-}{ }^{1}$ of kinetin. Calli treated with $30 \mathrm{~g}$ of sucrose resulted in the best secondary metabolites, containing alkaloids, phenols, flavonoids, saponins, and steroids.
\end{abstract}

Keywords: 2.4-D, 2.4-dichlorophenoxyacetic acid, callus, Myrmecodia tuberosa, kinetin, secondary metabolite, sucrose

\section{INTRODUCTION}

The ant nest plant (Myrmecodia tuberosa) is a herbal medicine that contains bioactive compounds, such as glycosides, vitamins, minerals, flavonoids, tocopherols, polyphenols, and tannins (Engida et al. 2013; Sanjaya et al. 2014; Sudiono et al. 2015), which are useful as antioxidants and anticancer compounds. Several researchers have shown that the ant nest plant inhibits the growth of various types of cancer cells, such as those in ovarian cancer (Hasanuddin et al. 2015), oral tongue squamous cell carcinoma (OTSCC) (Supriatno 2014), lung and colon cancer (Manoi 2008; Subroto and Saputro 2008), HeLa and MCM-B2 cell cancer (Soeksmanto et al. 2010). Another report showed that the ant nest plant has anti-microbial bioactivity and antioxidants (Prachayasittikul et al. 2008).

The popularity of the ant nest plant as a pharmaceutical plant is undoubtedly, causing many people to explore directly from nature. The over exploration of the Myrmecodia plant without cultivation might decrease the population. Thus, there is an urgent need to restore the natural population of this plant and use an alternative pharmaceutical source without taking it directly from nature. The tissue culture method is an alternative to provide raw material to produce a medicinal compound to achieve great benefits in the pharmaceutical aspect (Radha et al. 2011) and to select genotypes that have considerable amounts of bioactive compound (Cantelmo et al. 2013). Generally, organ culture, cell suspension, and callus culture have been used to study secondary metabolite synthesis using the tissue culture method (George and Sherrington 1984; Smetanska 2008). Massive development through tissue culture indicates that it does not affect the active compound content from the plants.

To assess biomass accumulation and synthesis of secondary compounds in cultures, various strategies have been developed. Biomass accumulation and metabolite biosynthesis are two-stage events. The first stage is to control the parameters, including regulation the growth and multiplication of both cultured cells/organs and biomass accumulation, as well as parameters that related to biosynthesis of metabolites which are controlled in the next step. Further, to select high-producing cells or organ clones; optimize medium parameters such as suitable medium, salt, sugar, nitrogen, phosphate, and plant growth regulator levels; and physical factors such as temperature, illumination, light quality, medium $\mathrm{pH}$, agitation, aeration, and environmental gas (e.g., oxygen, carbon dioxide, and ethylene) can be controlled in the 
early stage of the culture process. Meanwhile, in the second stage of the culture process, elicitation, replenishment of nutrient and precursor feeding, permeabilization, and immobilization strategies that assist with the accumulation of metabolites can be applied. In addition, in line with stage-specific strategies, to produce huge number of biomass in accordance with an increase in the accumulation of secondary compounds can be also possible (Murthy et al. 2014).

The successful tissue culture depends on factors such as the medium, growth regulator, explant source, and environment. In addition, the successful tissue culture has been also affected by the types and concentration of the growth regulator added in the medium (Shi 2014). Auxin, cytokinin, and gibberellin are growth regulators usually used in tissue culture (Davies 2010; Coggins and Lovatt 2014; Erland et al. 2017). One of the auxins, 2.4dichlorophenoxyacetic acid (2.4-D) which is a synthetic growth regulator, is beneficial to induce callus formation (Welsh and Mogea 1991; Phua et al. 2016). Nevertheless, proper interaction between auxin and cytokinin should be considered to enhance callus growth.

Past researchers have stated that the highest weight of callus was obtained from $1.00 \mathrm{mg} \cdot \mathrm{L}^{-1}$ of BA in combination with $0.99 \mathrm{mg} \cdot \mathrm{L}^{-1}$ of 2.4-D in Solanum khasianum (Tambe 2013) and $3.0 \mathrm{mg} \cdot \mathrm{L}^{-1}$ of 2.4-D in Gardenia latifolia (Reddy and Saritha 2012). Meanwhile, Sari and Kusuma (2015) revealed that an ant nest plant callus was formed in solid and liquid Murashige and Skoog (MS) medium with 2.4-D $\left(2 \mathrm{mg} \cdot \mathrm{L}^{-1}\right)$ and kinetin $\left(2 \mathrm{mg} \cdot \mathrm{L}^{-1}\right)$. In addition, a high quality of callus can be produced using specific nutrients and manipulate nutrient components in the culture medium (e.g., carbon source, nitrogen, and phosphate) to induce cell growth for effectiveness of secondary metabolite production (Tapia et al. 2001).

Sucrose has a positive effect on the production of secondary metabolites both in cell and organ cultures (Paiva and Janick 1982; Fowler 1983). The effect of sucrose concentration (i.e. 20, 30, 40 and $60 \mathrm{~g} \mathrm{~L}^{-1}$ ) was investigated in suspension cultures of Panax notoginseng for production of ginseng saponin (secondary metabolite) and polysaccharide (primary metabolite). In addition, a sugar feeding strategy was formulated to enhance the saponin accumulation by $P$. notoginseng cells (Zhang et al. 1996). Sucrose concentration (5, 7, and 9\% $\mathrm{w} / \mathrm{v})$ showed increased accumulation of phenols, flavonoids, chlorogenic acid, and total hypericin in adventitious root cultures of Hypericum perforatum $\mathrm{L}$ (Cui et al. 2010). Sucrose levels below 6-9\% did not significantly alter the specific alkaloid content, but biomass production by Solanum aviculare hairy roots was maximum and about $60 \%$ higher than in 3\% sucrose medium when the initial sucrose concentration was $4-6 \%$ (Yu et al. 1996). The suitable medium for both biomass Brahmi (Bacopa monnieri) $(6.31 \pm 0.12 \mathrm{~g}$ fresh weight and $250 \pm 5.00 \mathrm{mg}$ dry weight) and bacoside A accumulation (13.09 $\mathrm{mg} \mathrm{g}^{-1}$ dry wt) found in MS medium supplemented with $2 \%$ sucrose and $\mathrm{pH}$ set at 4.5 (Naik et al. 2010).
Based on the information above, the purpose of this research was to determine the optimum combination of growth regulators $\left(2.4-\mathrm{D}: 0.5,1,1.5\right.$, and $2 \mathrm{mg} \cdot \mathrm{L}^{-1}$ and kinetin $2 \mathrm{mg} \cdot \mathrm{L}^{-1}$ ) and explant source (cotyledon, stem, tuber, and root) on callus production in the ant nest plant using an in vitro method. The research was also aimed to evaluate the optimum sucrose concentration to enhance secondary metabolite production from the callus.

\section{MATERIALS AND METHODS}

\section{Plant materials}

Seeds of the ant nest plant (Myrmecodia tuberosa L. family Rubiaceae) were provided from the ripe fruit, which were collected from Antutan village, Tanjung Palas regency, Bulungan district, North Borneo. The seeds collection has been granted and permitted by the head of local authority (reference 025/RT-004/ATT/XI/2017)

\section{Sample preparation}

Seeds were sterilized using $70 \%$ alcohol for 1 minute, followed by $30 \%, 20 \%$, and $10 \%$ natrium hypochlorite $(\mathrm{v} / \mathrm{v})$ for 10 minutes each and washed three times for 5 minutes in sterile conditions. For germination, seeds were placed in MS medium and agar $\left(7.5 \mathrm{~g} \mathrm{~L}^{-1}\right)$ with $30 \mathrm{~g} \mathrm{~L}^{-1}$ sucrose (Murashige and Skoog 1962).

\section{Seed germination}

Sterile seeds of the ant nest plant were grown in glass bottles, containing MS0 (basal medium without plant growth regulators), incubated in a culture room with a light intensity of \pm 1000 -2000 Lux with a temperature of $20^{\circ} \mathrm{C}$ $25^{\circ} \mathrm{C}$. After one month, the seedling plant was used as an explant source, which was grown in a callus formation medium. The cotyledon, hypocotyl, tuber, and root were used as explant sources.

\section{Callus formation}

Cotyledon from a month-old plant was prepared to use as an explant source. The explant was grown in MS with a growth regulator combination of 2.4-D $(0.5,1,1.5$, and 2 $\left.\mathrm{mg} \cdot \mathrm{L}^{-1}\right)$ and kinetin $\left(2 \mathrm{mg} \cdot \mathrm{L}^{-1}\right)$, incubated in a tissue culture room with a light intensity of $\pm 1000-2000$ lux with a temperature of $20^{\circ} \mathrm{C}-25^{\circ} \mathrm{C}$ for 10 weeks. All growth regulation concentration was selected as described in previous experiment (Sari and Kusuma 2015). All treatment was done in triplicates.

\section{Sucrose treatment}

The best callus from induction was used in sucrose treatment. The $0.5 \mathrm{~g}$ callus was weighed and placed in the MS medium that was added with different concentrations of sucrose $(30,60,90$, and $120 \mathrm{~g})$. After 8 weeks, secondary metabolite content was determined from each callus. 


\section{Secondary metabolite extraction}

The callus was extracted using ethanol as a solvent for $48 \mathrm{~h}$. The extraction process continued until the extraction solution become clear $( \pm 48 \mathrm{~h})$ followed by filtration using Whatman paper (Whatman 2; Sigma-Aldrich, Germany). After filtration, a rotary evaporator was used to evaporate the remaining solvent. The extracted ethanol was then collected to be used as a sample extract in the phytochemical test to determine the phytochemical contents in the ant nest plant extract.

\section{Phytochemical test}

To detect the presence of possible phytochemicals in the sample extract, some phytochemicals, such as alkaloids, flavonoids, phenols, saponins, and steroids/triterpenoids, were tested, following the methods of Pal et al. (2012). For the alkaloid test (Mayer's test), $1 \mathrm{~mL}$ of Wagner's reagent was added to the extracted sample. The formation of a white precipitate indicates a positive test. In the flavonoid test (Shinoda's test), $5 \mathrm{~mL}$ of extract and $1 \mathrm{~mL}$ of concentrated hydrochloric acid and magnesium ribbon were mixed and shaken. The appearance of a pink-red color indicates the presence of flavonoids. For the phenolic test, the extracted sample was mixed with a few drops of $1 \%$ solution of $\mathrm{FeCl}_{3}$. A blue-green or black coloration indicates the presence of phenol. In the saponin test (foam test), the extracted sample was added to $10 \mathrm{~mL}$ of distilled water, cooled, air dried, and shaken vigorously for $10 \mathrm{~s}$. The appearance of stable foam (1-3 height) indicates the presence of saponin. In the steroid/triterpenoid test (Liebermann-Burchard test), $\mathrm{CH}_{3} \mathrm{COOH}$ glacial and absolute $\mathrm{H}_{2} \mathrm{SO}_{4}$ were added to the sample extract with a ratio of 20:1. The appearance of a blue or green color indicates the presence of steroids, and the appearance of a red or brown color indicates the presence of triterpenoids.

\section{Data analysis}

The results were presented as descriptive data. Callus induction was observed at the first growth of the callus along with the percentage of callus growth, callus morphology (texture and color), and callus growth intensity. For the phytochemical test, the presence or absence of phytochemicals such as alkaloids, flavonoids, phenols, saponins, triterpenoids, and steroids in the extract was indicated as positive (presence) or negative (absence). Weight of callus which were obtained after various concentration of sucrose treatment were analysed by using ANOVA (SPSS 22, Inc., USA), followed by Tukey's post hoc test to evaluate any significant differences at $\mathrm{p}<0.05$.

\section{RESULTS AND DISCUSSION}

\section{Seed germination}

The seeds of the ant nest plant that were grown in MS0 started to grow on day 3 , reaching full growth as a plant at day 30 (Figure 1).

Seed germination is a mechanism related to the alteration of both morphological and physiological aspects, which is caused by embryo activation. The process of embryo expansion and elongation is a process that is initiated by absorbing water by the seed before germination. The germination process is terminated when the radicle has completely grown out to cover the seed layers (Hermann et al. 2007).

Seed germination of the ant nest plant using tissue culture was affected by two types of factors: internal and external factors. The internal factors include the endosperm (food stores) and the level of seed maturity. In agreement with the findings by Miransari and Smith (2009), for the seed to germinate, the availability of starches, proteins, lipids, and nutrients must be completed in the seed embryo through the activity of specific enzymes and pathways. Müller et al. (2013) added that the activity of the enzyme pectin methylesterases is also influenced in seed germination. Further, the homogalacturonans of the wall, a methyl esterified, are facilitated by the enzyme that affects the cell-wall porosity and elasticity, causing cell growth and water uptake. In addition, the expansion of the cell wall of the radicle and the tissues occurs during the process of seed germination.

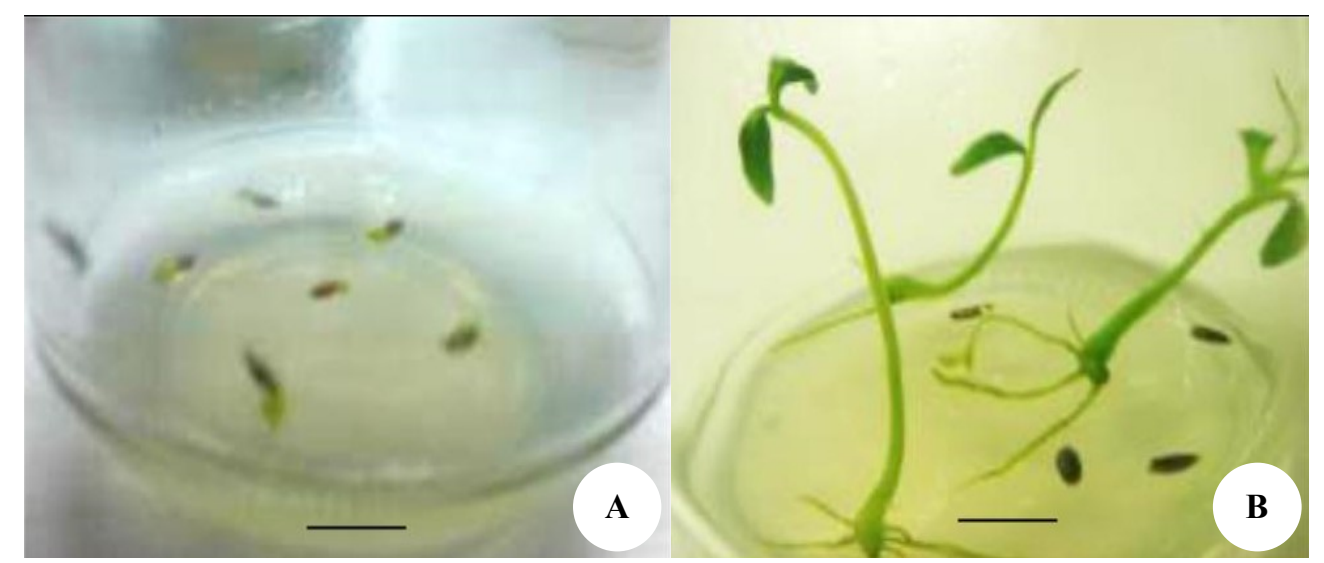

Figure 1. Seed germination of the ant nest plant (Myrmecodia tuberosa) in MS0 medium. A. 3 days, B. 30 days. Bar $=1 \mathrm{~cm}$ 
Besides internal factors, seed germination is also affected by external factors, such as plant growth regulators, light, and medium composition. The successful seed germination of the ant nest plant in a brief time is influenced by the MS medium composition, which contains several amino acids that might boost seed germination. Waes and Debergh (1986) reported that the addition of amino acids, such as serine, glutamic acid, peptone, hydrolysate casein, and yeast extract, in the medium induce seed germination. In comparison with other salt formation, MS inorganic salts have high contents of nitrate, potassium, and ammonium. The MS medium also contains high macro and microelements and inorganic salts that are sufficient to support the optimum growth of the plant. In addition, the concentration and quality of nitrogen in the MS medium contribute to the prolific growth obtained with plantderived seed types that are incubated in this medium. Thus, the nitrogen supplied in the medium is in inorganic form as the anion $\mathrm{NO}_{3}$ or the cation $\mathrm{NH}_{4}$. According to Malmgren (1996), the ammoniated form of nitrogen is more beneficial than the nitrate form, which is proved by the fastest growth of the Dactylorhiza species seedlings at $50-100 \mathrm{mg} \cdot \mathrm{L}^{-1}$ $\mathrm{NH}_{4} \mathrm{NO}_{3}$. Similar results were found in past research, which revealed that an efficient concentration of organic and inorganic nitrogen sources can be used to promote the growth of explants (Chen and Chang 2002). The 30-day old ant nest plant was used as an explant source to be grown in the initial medium treatment.

\section{Callus induction}

Callus induction of cotyledon, stem, tuber, and root explants of the ant nest plant was affected by the combination of growth regulators 2.4-D and kinetin (Table $1)$.

Table 1. Effects of 2.4-D and kinetin composition on the callus induction of the ant nest plant (Myrmecodia tuberosa Jack) from the cotyledon, stem, tuber, and root explants at week 10

\begin{tabular}{|c|c|c|c|c|c|c|c|}
\hline \multirow[b]{2}{*}{ Explant } & \multicolumn{2}{|c|}{ Growth regulator } & \multirow{2}{*}{$\begin{array}{c}\text { Percentage of } \\
\text { callus formation } \\
(\%)\end{array}$} & \multirow{2}{*}{$\begin{array}{c}\text { Callus } \\
\text { formation time } \\
\text { (week) }\end{array}$} & \multicolumn{2}{|c|}{ Callus morphology } & \multirow[b]{2}{*}{$\begin{array}{c}\text { Callus } \\
\text { intensity }\end{array}$} \\
\hline & $\begin{array}{c}2.4-\mathrm{D} \\
\mathrm{mg} \cdot \mathrm{L}^{-1}\end{array}$ & $\begin{array}{c}\text { Kinetin } \\
\mathrm{mg} \cdot \mathrm{L}^{-1}\end{array}$ & & & Color & Texture & \\
\hline \multirow[t]{8}{*}{ Cotyledon } & 0.5 & 0.0 & 100 & 2 & Yellow & Friable & ++ \\
\hline & 1.0 & 0.0 & 100 & 2 & Yellow & Friable & ++ \\
\hline & 1.5 & 0.0 & 100 & 2 & Yellowish green & Friable & ++ \\
\hline & 2.0 & 0.0 & 100 & 2 & yellowish green & Friable & ++ \\
\hline & 0.5 & 2.0 & 100 & 2 & Yellowish green & Friable & +++ \\
\hline & 1.0 & 2.0 & 100 & 2 & Yellowish green & Friable & +++ \\
\hline & 1.5 & 2.0 & 100 & 2 & Yellowish green & Friable & +++ \\
\hline & 2.0 & 2.0 & 100 & 2 & Green-yellowish green & Friable & +++ \\
\hline \multirow[t]{8}{*}{ Stem } & 0.5 & 0.0 & 100 & 2 & Yellowish green & Friable & ++ \\
\hline & 1.0 & 0.0 & 100 & 2 & Yellow & Friable & ++ \\
\hline & 1.5 & 0.0 & 100 & 2 & Yellowish green & Friable & ++ \\
\hline & 2.0 & 0.0 & 100 & 2 & Yellow & Friable & ++ \\
\hline & 0.5 & 2.0 & 100 & 2 & Yellow & Friable & +++ \\
\hline & 1.0 & 2.0 & 100 & 2 & Yellowish green & Friable & +++ \\
\hline & 1.5 & 2.0 & 100 & 2 & Yellowish green & Friable & +++ \\
\hline & 2.0 & 2.0 & 100 & 2 & Yellowish green & Friable & +++ \\
\hline \multirow[t]{8}{*}{ Tuber } & 0.5 & 0.0 & 100 & 2 & Yellowish green & Friable & ++ \\
\hline & 1.0 & 0.0 & 100 & 2 & Yellowish green & Friable & ++ \\
\hline & 1.5 & 0.0 & 100 & 2 & Yellowish green & Friable & ++ \\
\hline & 2.0 & 0.0 & 100 & 2 & Yellow & Friable & ++ \\
\hline & 0.5 & 2.0 & 100 & 2 & Yellowish green & Friable & +++ \\
\hline & 1.0 & 2.0 & 100 & 2 & Yellow & Friable & +++ \\
\hline & 1.5 & 2.0 & 100 & 2 & Yellow & Friable & +++ \\
\hline & 2.0 & 2.0 & 100 & 2 & Yellowish green & Friable & +++ \\
\hline \multirow[t]{8}{*}{ Root } & 0.5 & 0.0 & 100 & 2 & Yellowish green & Friable & + \\
\hline & 1.0 & 0.0 & 100 & 2 & Yellowish green & Friable & + \\
\hline & 1.5 & 0.0 & 100 & 2 & Yellowish green & Friable & ++ \\
\hline & 2.0 & 0.0 & 100 & 2 & Yellowish green & Friable & ++ \\
\hline & 0.5 & 2.0 & 100 & 2 & Yellowish green & Friable & +++ \\
\hline & 1.0 & 2.0 & 100 & 2 & Yellowish green & Friable & +++ \\
\hline & 1.5 & 2.0 & 100 & 2 & Yellowish green & Friable & +++ \\
\hline & 2.0 & 2.0 & 100 & 2 & Yellowish green & Friable & +++ \\
\hline
\end{tabular}

Note: $+=$ low,$++=$ intermediate,$+++=$ high. Three explants were used for each PGRs combination 
All treatment combinations of growth regulators resulted in calli with a percentage of $100 \%$. A callus is a collective form of disorganised cell masses. The formation of callus via growth and accumulation of cells has a relationship with wounding. Further, a single differentiated cell and other totipotent cells could produce a callus that can regenerate the whole plant body (Nagata and Takebe 1971). The callus is formed at 2 weeks of age, marked by explant swelling and callus formation in the edge, slice, or lesion of the explant. The callus is fully formed at the leaf surface after a month. This is related to the uptake of nutrition in the medium by the explant. The absorption of nutrients is even better with direct contact between the medium and explant.

This result was in line with previous research performed by Morini et al. (2000), which revealed that the callus formation of quince leaves was found only in the abaxial surface part. The appearance of the callus on the injured part might be because of the excitement of the tissue on the explant to cover the wound. Explant response on the treatment medium is started with explant swelling or elongation. The size of the explant becomes bigger from the beginning, and the callus begins to form on part of the injured explant. The combination of auxin (2.4-D) and cytokinin (kinetin) as growth regulators on the MS medium can induce callus formation, both in single and combination treatments. The callus began to appear on the edge of the explants and on the wounded parts and continued to grow until the end of the observation at 10 weeks after planting. In addition, Stobbe et al. (2002) revealed that the wound-induced calli regenerate new organs or new tissues, suggesting that they are highly pluripotent.

In 2.4-D without kinetin, callus growth response in all explants (cotyledon, stem, tuber, and root) with a small callus needed extended time to grow bigger. This suggests that the ant nest plant callus cannot grow optimally with a single auxin administration without the addition of a growth regulator from the cytokine group. According to Kala et al. (2014), the growth regulators cannot induce a callus from $C$. parviflorum leaf explants. However, the combinations of growth regulators resulted in optimum callus production. Callus formation is strongly influenced by the type and concentration of the growth regulator. Zulfiqar et al. (2009) revealed that the growth and morphogenesis of plants in vitro are controlled by the balance and interaction of the growth regulator that was absorbed from the media. Auxins play a role in stimulating the growth of explant cells; thus, auxin tends to form a callus that begins from cell division in the meristematic area. At the beginning of the growth response, auxin triggered the elongation of cells through loosening the cellulosic cell wall. This elongation of the cell was due to the response of 2.4-D, but the cell cannot divide rapidly because there was no addition of kinetin. The combination of the growth regulators, 2.4-D, and kinetin, in all explant sources (cotyledons, stems, tubers, and roots) resulted in a larger callus size compared to only $2.4-\mathrm{D}$. In line with past research (Rout et al. 2000), the combination of 2.4-D and kinetin resulted in the largest callus of Cephaelis ipecacuanha and Melaleuca alternifolia (Kiong et al. 2007). Stella and Braga (2002) used a combination of auxin (picloram) and cytokinin (kinetin) in the callus of Rudgea jasminoides. The best callus was found through the addition of $2 \mathrm{mg} \cdot \mathrm{L}^{-1}$ of $2.4-\mathrm{D}$ and $2 \mathrm{mg} \cdot \mathrm{L}^{-1}$ of kinetin in all explants that were used. In addition to the larger callus size, the resulting callus had a more intensive green color with friable callus texture. The large callus size might be due to the corresponding concentration of growth regulators, causing rapid cell division in the ant nest explants. The callus can be provided with two plant hormones, auxin, and cytokinin in a balanced condition. Pande et al. (2015) also got highest callus induction frequency on MS media supplemented with $1.5 \mathrm{mg} \mathrm{\textrm {L } ^ { - 1 }}$ 2, 4-Dichlorophenoxyacetic acid, and $1.5 \mathrm{mg} \mathrm{L}^{-1}$ of Benzyl amino purine.

\section{Callus color}

The results of the observation for 10 weeks after planting found that the combination of growth regulator 2.4-D and kinetin on the MS medium induced the formation of a callus on various explants from the ant nest plants (Figure 2). The color of the calli at all treatments ranged from yellow and yellowish green to green. The resulting color variations might be due to the diverse types of growth regulators, the difference in growth regulator concentration, and the type of explant. Compared to only auxin, a combination of auxin and cytokinin resulted in a callus color that was more green, caused by cytokinin, which tends to promote chlorophyll formation (Edwin $\mathrm{F}$ George et al. 2008). According to Afshari et al. (2011), various callus color conditions could be caused by the pigmentation, the influence of light, and the plant parts used as the source explant.

Based on the callus color (Figure 2), the addition of $2 \mathrm{mg} \cdot \mathrm{L}^{-1}$ of $2.4-\mathrm{D}$ and $2 \mathrm{mg} \cdot \mathrm{L}^{-1}$ of kinetin resulted in assorted colors from pale green and yellowish green to green. The green color of the callus of the ant nest plant was because of the chlorophyll content. The chlorophyll was formed in the callus due to the addition of the growth regulator 2.4-D and kinetin. Kinetin from the cytokinin group is involved in the chlorophyll formation in the callus along with the existence of light. This finding was in line with previous research by Leupin et al. (2000), which reported that the color change in callus to green was because of chlorophyll formation.

Meanwhile, the yellow to yellowish green callus (Table 1) was found because of the kinetin concentrations added to the media, which had a lower concentration than 2.4-D. Kinetin as a cytokinin stimulated chlorophyll formation, whereas auxin can be an inhibitor. According to George and Sherrington (1984), the decrease in the formation of chlorophyll with 2.4-D was found in the culture of peas and potatoes. In addition, the yellow color callus was also caused by the chlorophyll degradation process, lack of kinetin, and low kinetin concentration. In addition, kinetin plays a role in the formation of chlorophyll, causing the green color to appear. 


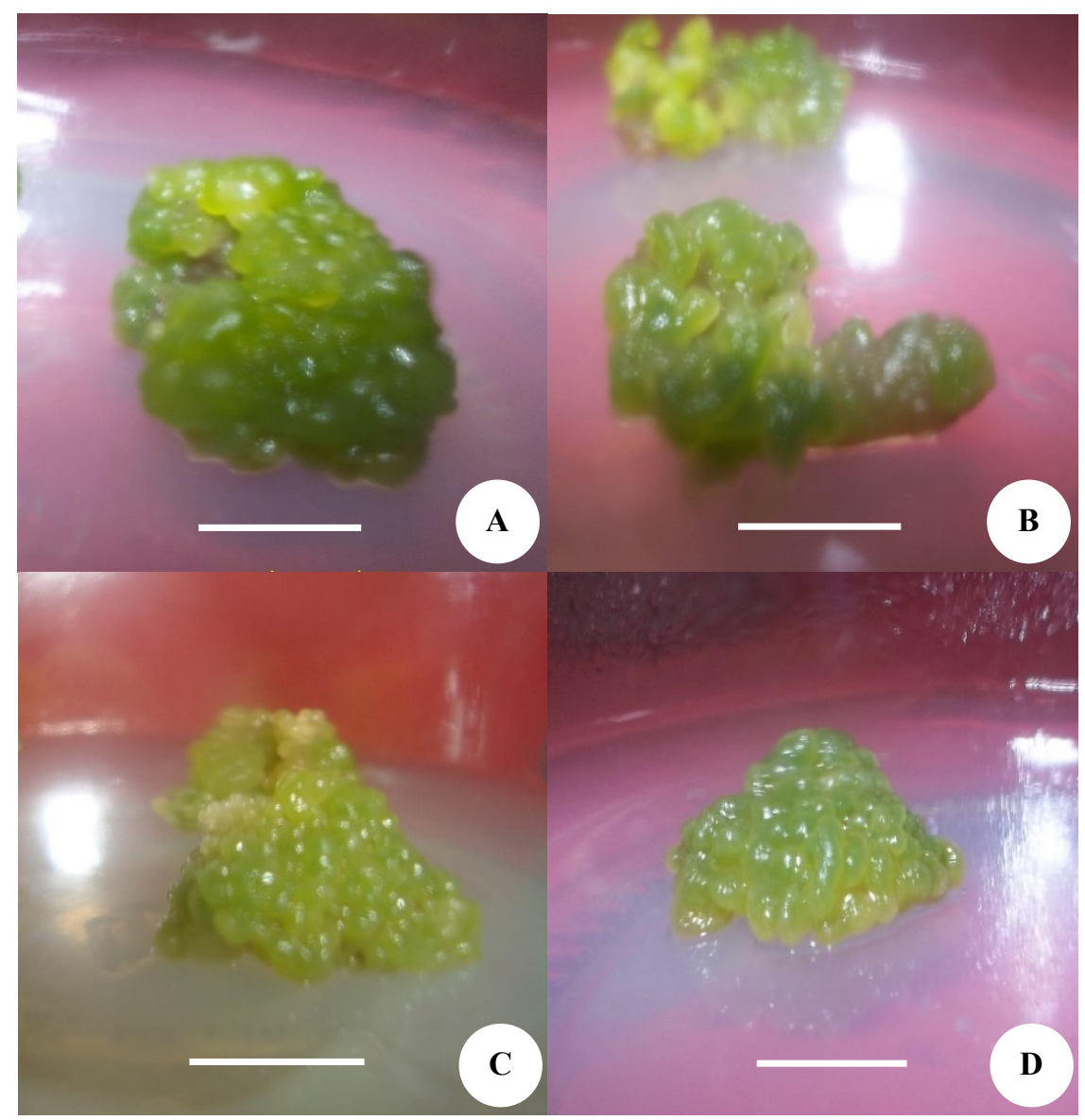

Figure 2. Optimum calli at a concentration of $2 \mathrm{mg} \cdot \mathrm{L}^{-1}$ of $2.4-\mathrm{D}$ and $2 \mathrm{mg} \cdot \mathrm{L}^{-1}$ of kinetin at 10 weeks after planting in explant. A. Cotyledon, B. Stem, C. Tuber, D. Root. Bar $=1 \mathrm{~cm}$

\section{Callus texture}

Table 1 shows friable callus was found in calli with all treatments. The friable callus was formed through the growth of cells at a small size and loose cell interaction that was affected by the occurrence of auxin. Previous researchers reported that 2.4-D stimulated cell elongation by increasing of plasticity of the cell wall to become loose, causing water to easily flow to the inner cell by osmosis, causing the cell to become elongated (Robbiani et al. 2010). Thus, friable calli contain much water because the wall cell has not reached lignification yet, and the group of cells can be easily separated from the others. The callus texture from the explant can be distinguished as friable and non-friable. The non-friable callus has compact and tight cells that are difficult to separate. In contrast, a friable callus from an explant has loose cell interaction that is easily detached using tweezers.

The addition of growth regulator with a combination of 2.4-D and kinetin on various explants formed a friable texture in the callus (Figure 2). The friable callus was also obtained in a study conducted by Sari and Kusuma (2015), which reported that the friable callus was also obtained on ant nest cotyledons planted in solid and liquid MS media.
In line with Chakraborty et al. (2013), the MS medium with 2.4-D $\left(0.5 \mathrm{mg} \cdot \mathrm{L}^{-1}\right)$ and kinetin $\left(0.2 \mathrm{mg} \cdot \mathrm{L}^{-1}\right)$ resulted in the best explant Withania somnifera (L.) for callusing with soft, friable, and greenish white features. The addition of growth regulators in the medium caused the callus cells to be active in cell division and cell enlargement, raised the osmotic pressure, and increased protein synthesis.

The current visual results indicated that the appearance of the callus with only the 2.4-D and with the 2.4-D and kinetin combination produced a friable callus and formed nodules (globular). This indicated that the callus can be further grown into shoots or plantlets. Purnamaningsih (2016) stated that the callus structure usually describes regeneration potency to form buds and roots. The friable callus has a higher ability to form buds than the compact callus. In this case, the growth regulator increased callus regeneration. In addition, the growth of the callus was also greatly affected by the nutrient balance.

\section{Sucrose treatment}

The weight gain of the callus was significantly affected by different concentrations of sucrose. The average weight gain of the callus is shown in Table 2. 
Table 2. Callus morphology and average of weights of the callus of the ant nest plant (Myrmecodia tuberosa) treated with different concentrations of sucrose for 8 weeks

\begin{tabular}{|c|c|c|c|}
\hline \multirow{2}{*}{$\begin{array}{l}\text { Sucrose } \\
\text { (g) }\end{array}$} & \multicolumn{2}{|c|}{ Callus morphology } & \multirow{2}{*}{$\begin{array}{l}\text { Mean weight of } \\
\text { callus (g) }\end{array}$} \\
\hline & Color & Texture & \\
\hline 30 & Green & Friable & $2.12 \pm 0.40^{\mathrm{d}}$ \\
\hline 60 & $\begin{array}{l}\text { Green-yellowish } \\
\text { green }\end{array}$ & Friable & $1.60 \pm 0.18^{\mathrm{c}}$ \\
\hline 90 & Yellowish green & Friable & $1.15 \pm 0.28^{\mathrm{b}}$ \\
\hline 120 & Yellowish green & Friable & $0.68 \pm 0.69^{\mathrm{a}}$ \\
\hline
\end{tabular}

Note: Different letters $(\mathrm{a}, \mathrm{b}, \mathrm{c})$ indicate significantly different means for different treatments at $p<0.05$ using Tukey's test

\section{Callus morphology}

Callogenesis is the initial response, characterized by the formation of the callus, which starts from the edge of the explant (wounded part) at the top and bottom that has direct contact with the medium. The callus is formed faster on the part that has direct contact with the media. This is probably related to the process of nutrient uptake in the medium by the explant. The appearance of the callus on the wounded part might be caused by the excitement of the tissue on the explant to cover the wound. George and Sherrington (1984) stated that the cell division that leads to the callus formation occurs from the injuries and both the natural and artificial hormone supply from the outside into the explant.

Light is an external factor that influences callus formation. The color change that exists in the callus was because of pigment, nutrients, and environmental factors, such as light (Evans et al. 2003). George and Sherrington (1984) stated that white light could induce callus formation and organogenesis in the plant tissue. A callus that has yellowish green and green color was formed with the addition of kinetin. The green color was because of chlorophyll, resulting from the $2.4 \mathrm{D}$ interaction with kinetin, mainly because kinetin (cytokinin) has a function in the formation of chlorophyll in the callus and due to environmental factors, such as exposure to light. Leupin et al. (2000) claimed that the color change in the callus from white to green was due to chlorophyll formation.

\section{Callus growth}

The largest mean $(2.12 \mathrm{~g})$ of callus weight of the ant nest plant was found in sucrose-treated medium at $30 \mathrm{~g} \mathrm{~L}^{-1}$ (Table 2). However, the sucrose-treated medium leads to reduced callus weight. In the treatment of $60 \mathrm{~g} \mathrm{~L}^{-1}$, sucrose decreased the weight of the callus to $1.60 \mathrm{~g}$. This was due to the increasing concentration of medium that inhibited the absorption of water and minerals. These inhibitory effects were found in the 90 and $120 \mathrm{~g} \mathrm{~L}^{-1}$ sucrose-treated medium, resulting in a mean weight of callus of 1.15 and $0.68 \mathrm{~g}$. Based on the current results, it can be estimated that the sucrose-treated medium above $30 \mathrm{~g} \mathrm{~L}^{-1}$ can inhibit the growth of the $M$. tuberosa callus. Lindsey and Yeoman (1983) stated that the inhibition of growth in cultures that produced secondary metabolites is probably due to a competition between primary metabolism and secondary metabolism for the same substance. The M. tuberosa plant is a medicinal plant for which the callus formation in the tissue culture also has the same secondary metabolite content with the original plant in nature.

The current results found that the callus color ranged from green to yellowish green. The callus color indicates the presence of chlorophyll in the tissues. The green callus was present in MS-treated medium with a sucrose concentration of 30 and $60 \mathrm{~g} \mathrm{~L}^{-1}$. The greener color callus indicates more chlorophyll content, which can support the growth of the callus. The yellowish green callus was also found in the sucrose treatment with different concentrations: 90 and $120 \mathrm{~g} \cdot \mathrm{L}^{-1}$. The resulting color variation was caused by the difference in sucrose concentration in each treatment. This finding is in agreement with that of George and Sherrington (1984) in which sucrose in the tissue culture media can inhibit chlorophyll synthesis with varying levels of inhibition, depending on the tissue and plant species. The accumulation of sucrose in cells can also inhibit the process of photosynthesis because of the accumulation of sucrose in the cell, causing the demand of sugar in the cell to be fulfilled. As a result, the cells inhibit photosynthesis and the formation of chlorophyll.

Growth in tissue culture can be characterized by the increase of the wet weight of the callus. Physiologically, the weight of the wet callus consists of water and carbohydrates that have a relationship with sucrose in the culture medium as a carbon source and osmotic regulator, which is critical for embryoid and callus formation (Last and Brettell 1990). Sucrose can be rapidly hydrolyzed to form glucose and fructose, increasing the osmolality of the medium. In this study, the sucrose-treated medium entered the plant cell through diffusion and osmosis processes. Shahnewaz and Bari (2004) revealed that the effect of sucrose concentration influences the callus induction frequency that might be due to its contribution to the osmotic potential of the medium instead of its utilization as a carbon source.

In cell metabolism, glucose and fructose enter into the glycolysis and Krebs cycle to form ATP to be used for callus growth. Perry et al. (1987) revealed the change in solute content (e.g. carbon source) could cause various change in turgor and osmotic turgor. In tissue culture, turgor pressure might cause elongation and magnification of callus cells. Furthermore, turgor pressure might be different in each cell, and the cell growth response to the addition of carbohydrates also varies for each species.

\section{Phytochemical test}

The phytochemical test results of the callus of the ant nest plant with different concentrations of sucrose are shown in Table 3 . 


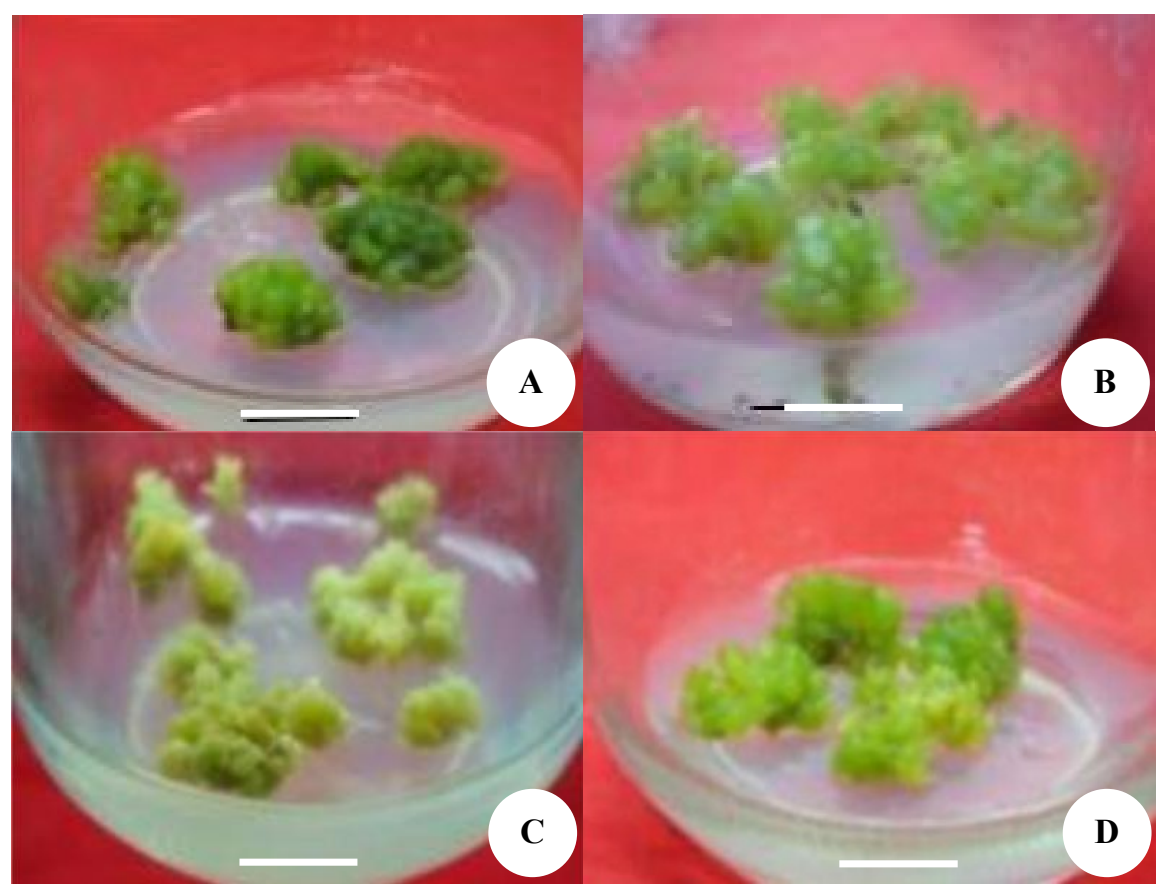

Figure 3. Callus of the ant nest plant (Myrmecodia tuberosa) with different concentrations of sucrose. A. $30 \mathrm{~g} \cdot \mathrm{L}^{-1}, \mathrm{~B} .60 \mathrm{~g} \cdot \mathrm{L}^{-1}, \mathrm{C}$. $90 \mathrm{~g} \cdot \mathrm{L}^{-1}$, D. $120 \mathrm{~g} \cdot \mathrm{L}^{-1}$ for 8 weeks. Bar $=1 \mathrm{~cm}$

Table 3. Phytochemical screening test of the ant nest plant callus with different sucrose concentrations

\begin{tabular}{|c|c|c|c|c|c|c|}
\hline Sucrose (g) & Flavonoid & Phenol & Alkaloid & Saponin & Steroid & Triterpenoid \\
\hline 30 & ++ & ++ & ++ & ++ & ++ & - \\
\hline 60 & + & + & + & + & + & - \\
\hline 90 & + & + & + & + & + & - \\
\hline 120 & + & + & + & + & + & - \\
\hline
\end{tabular}

The phytochemical test on the ant nest plant calli treated with different sucrose concentrations found that metabolite content was positive from each treatment, which contained flavonoids, phenols, alkaloids, and steroids, whereas a negative result was found for triterpenoid. The best sucrose treatment was obtained with the addition of $30 \mathrm{~g}$, resulting in a more concentrated test color than the others. There was no change in metabolite content between the ant nest plant callus from the tissue culture and from nature. Sari et al. (2017) stated that all parts of the ant nest plant (tuber, stem, and leaves) from nature contained phenols, flavonoids, saponins, and alkaloids but not triterpenoid. According to Fowler (1983), the tissue culture method can be used to produce chemical compounds that are usually derived from the native plant as well as new compounds synthesis, which is not produced by the plant. The secondary metabolites synthesized from the explant with the tissue culture depend on the culture condition. The proper culture produces secondary metabolites that are similar to those of the native plant. Based on the utilization aspect, ant nest plants have various chemical compounds. The chemical compounds from this plant might have a role in the activity of pathogenic resistance, allelopathy, and body defense against pest attacks. The compounds are utilized by the plants as a self-defense system, while for humans, they are used as an active ingredient in medicine. According to Subroto and Saputro (2008), ant nest plants are rich in tocopherol antioxidants (vitamin E) and some important minerals (calcium) for the body.

Koes et al. (2005) stated that flavonoids can be synthesized in all parts of the plant that have a pivotal role in providing color, fragrance, and taste to the fruits, flowers, and seeds, which makes them attractants for insects, birds, or mammals and aids in pollen or seed transmission. In addition, Blount et al. (1992) stated that flavonoids that are very important in plant resistance against pathogenic bacteria and fungi also have antipathogenic properties that can be non-specific and result, in part, from their antioxidative properties. Moreover, Beckman (2000) added that flavonoids affect the tightening of the plant structures and tissues by stimulating auxin (IAA) activity, which promotes the differentiation of tissues and promotes of callus and tylose formation and the closure of the vascular system to protect against pathogen infection. 
Subroto and Saputro (2008) claimed that the function of flavonoids as an antiviral, including for the HIV virus (AIDS) and herpes virus, has been widely published. Moreover, flavonoids are also reported to play a pivotal role in the prevention and treatment of several diseases, such as cancer, asthma, cataracts, diabetes, gout, rheumatism, haemorrhoids, and periodontitis (inflammation of the connective tissue of the tooth root), protecting the cell structure, having a synergistic relationship with vitamin $\mathrm{C}$, and are anti-inflammatory and prevent bone loss.

Flavonoids and phenolic acids are major groups of secondary metabolites and bioactive compounds in plants (Kim et al. 2003). Both have a function as reducing agents, free radical scavengers, and quenchers of singlet oxygen formation. In addition, flavonoids and phenolic acid components play important roles in the control of cancer and other human diseases (Ghasemzadeh and Ghasemzadeh 2011). Meanwhile, phenolic compounds that are important for plant growth and reproduction are formed as a response to environmental factors, for example, light and chilling, pollution, etc.) and to defend wounded plants (Kefeli et al. 2003).

Besides flavonoids and phenols, alkaloids have certain pharmacological activity. Some of them are toxic to humans, but many also can be used in the medicinal field, such as to raise blood pressure, reduce pain, and fight microbial infections. In addition, alkaloids for plants, among others, function as toxic substances to fight insects or plant-eating animals (Subroto and Saputro 2008).

Another secondary metabolite, namely, saponin, a glycoside of triterpenes and steroids, is important for pharmaceuticals. Moreover, the underexplored biodiversity of plant saponins is likely to prove to be a vital resource for future drug discovery. Saponin is also one of the most numerous and diverse groups of natural plant products that serve a range of ecological roles, including plant defense mechanisms against disease and herbivores and possibly as allelopathy agents in competitive interactions between plants (Makkar et al. 2007).

In summary, this study indicates that $2 \mathrm{mg} \cdot \mathrm{L}^{-1}$ of $2.4-\mathrm{D}$ and $2 \mathrm{mg} \cdot \mathrm{L}^{-1}$ of kinetin can potentially be used to obtain the best callus from the cotyledon explant source. The study has also shown that alkaloid, flavonoid, phenol, saponin, and steroid are found in the secondary metabolites of the ant nest plant callus. Further research needs to be conducted to examine antioxidant profiles, antimicrobial properties and toxicity level of ant nest plant callus extract.

\section{ACKNOWLEDGEMENTS}

The authors would like to thank the Indonesian Government through the Ministry of Research and Technology, General Higher Education (Kemenristek DIKTI), Indonesia (Penelitian Unggulan Perguruan Tinggi/PUPT) contract number 359/un17.41/k1/2017 for financial support.

\section{REFERENCES}

Afshari R, Angoshtari R, Kalantari S. 2011. Effects of light and different plant growth regulators on induction of callus growth in rapeseed (Brassica napus L.) genotypes. Plant Omics 4 (2): 60.

Beckman CH. 2000. Phenolic-storing cells: keys to programmed cell death and periderm formation in wild disease resistance and in general defence responses in plants? Physiol Mol Plant Pathol 57 (3): 101-110.

Blount JW, Dixon RA, Paiva NL. 1992. Stress responses in alfalfa (Medicago sativa L.) XVI. Antifungal activity of medicarpin and its biosynthetic precursors; implications for the genetic manipulation of stress metabolites. Physiol Mol Plant Pathol 41 (5): 333-349.

Cantelmo L, Soares B, Rocha L, Pettinelli J, Callado C, Mansur E, Castellar A, Gagliardi R. 2013. Repetitive somatic embryogenesis from leaves of the medicinal plant Petiveria alliacea L. Plant Cell Tiss Org Cult 115 (3): 385-393.

Chakraborty N, Banerjee D, Ghosh M, Pradhan P, Gupta NS, Acharya K, Banerjee M. 2013. Influence of plant growth regulators on callus mediated regeneration and secondary metabolites synthesis in Withania somnifera (L.) Dunal. Physiol Mol Biol Plants 19 (1): 117 125.

Chen J-T, Chang W-C. 2002. Effects of tissue culture conditions and explant characteristics on direct somatic embryogenesis in Oncidium Gower Ramsey. Plant Cell Tiss Org Cult 69 (1): 41-44.

Coggins Jr CW, Lovatt CJ. 2014. 14 Plant Growth Regulators. Citrus Production Manual, 3539, 215.

Cui X-H, Murthy HN, Wu C-H, Paek K-Y. 2010. Sucrose-induced osmotic stress affects biomass, metabolite, and antioxidant levels in root suspension cultures of Hypericum perforatum L. Plant Cell Tiss Org Cult 103 (1): 7-14.

Davies PJ. 2010. The plant hormones: their nature, occurrence, and functions. In: Plant Hormones. Springer, Berlin.

Engida AM, Kasim NS, Tsigie YA, Ismadji S, Huynh LH, Ju Y-H. 2013. Extraction, identification and quantitative HPLC analysis of flavonoids from sarang semut (Myrmecodia pendan). Ind Crops Prod, 41: 392-396.

Erland LA, Shukla MR, Glover WB, Saxena PK. 2017. A simple and efficient method for analysis of plant growth regulators: a new tool in the chest to combat recalcitrance in plant tissue culture. Plant Cell Tiss Org Cult 1-12.

Evans DE, Coleman JOD, Kearns A. 2003. Plant Cell Culture. BIOS Scientific Publisher, New York.

Fowler M. 1983. Commercial applications and economic aspects of mass plant cell culture. Paper presented at the Seminar series-Society for Experimental Biology.

George EF, Hall MA, De Klerk G-J. 2008. Plant growth regulators II: cytokinins, their analogues and antagonists. In Plant Propagation by Tissue Culture. Springer, Berlin.

George EF, Sherrington PD. 1984. Plant Propagation by Tissue Culture (Handbook and Directory Of Commercial Laboratories). Eastern Press, UK.

Ghasemzadeh A, Ghasemzadeh N. 2011. Flavonoids and phenolic acids: Role and biochemical activity in plants and human. J. Med. Plants Res, 5 (31): 6697-6703.

Hasanuddin K, Supriadi G, Kurnia D, Adhita D. 2015. Potential of terpenoid bioactive compound isolated from Papua ant nest as an alternative ovarian cancer treatment. Open J Obstet Gynecol 5: 406411.

Hermann K, Meinhard J, Dobrev P, Linkies A, Pesek B, Heß B, Macháčková I, Fischer U, Leubner-Metzger G. 2007. 1Aminocyclopropane-1-carboxylic acid and abscisic acid during the germination of sugar beet (Beta vulgaris L.): a comparative study of fruits and seeds. J Exp Bot 58 (11): 3047-3060.

Kala SC, Mallikarjuna K, Aruna P. 2014. An efficient protocol devised for rapid callus induction from leaf explants of Biophytum sensitivum (Linn) DC. Intl J Phytopharm 4 (1): 20-24.

Kefeli VI, Kalevitch MV, Borsari B. 2003. Phenolic cycle in plants and environment. J Cell Mol Biol 2 (1): 13-18.

Kim D-O, Jeong SW, Lee CY. 2003. Antioxidant capacity of phenolic phytochemicals from various cultivars of plums. Food Chem 81 (3): 321-326.

Kiong ALP, Huan HH, Hussein S. 2007. Callus induction from leaf explants of Melaleuca alternifolia. Intl J Agric Res 2 (3): 227-237. 
Koes R, Verweij W, Quattrocchio F. 2005. Flavonoids: a colorful model for the regulation and evolution of biochemical pathways. Trends Plant Sci 10 (5): 236-242.

Last DI, Brettell RI. 1990. Embryo yield in wheat anther culture is influenced by the choice of sugar in the culture medium. Plant Cell Rep 9 (1): 14-16.

Leupin RE, Leupin M, Ehret C, Erismann KH, Witholt B. 2000. Compact callus induction and plant regeneration of a non-flowering vetiver from Java. Plant Cell Tiss Org Cult 62 (2): 115-123.

Lindsey K, Yeoman MM. 1983. The relationship between growth rate, differentiation and alkaloid accumulation in cell cultures. J Exp Bot 34 (145): 1055-1065.

Makkar HPS, Siddhuraju P, Becker K. 2007. Saponins. In Plant Secondary Metabolites. Humana Press. Totowa, NJ.

Malmgren S. 1996. Orchid propagation: theory and practice. Paper presented at the North American native orchids: propagation and production. North American Native Terrestrial Orchid Conference, Germantown, Maryland.

Manoi F. 2008. Ant-plants (Myrmecodia) potential medicinal plant to cure diseases. Warta Penelitian dan Pengembangan Tanaman Industri 14 (1): 26-30. [Indonesian].

Miransari M, Smith D. 2009. Rhizobial lipo-chitooligosaccharides and gibberellins enhance barley (Hordeum vulgare L.) seed germination. Biotechnol, 8 (2): 270-275.

Mohan Reddy Y, Saritha K. 2012. Callus induction and somatic embryogenesis of Gardenia latifolia Ait. Intl J Curr Sci 4: 83-89.

Morini S, D'Onofrio C, Bellocchi G, Fisichella M. 2000. Effect of 2,4-D and light quality on callus production and differentiation from in vitro cultured quince leaves. Plant Cell Tiss Org Cult 63 (1): 47-55.

Müller K, Levesque-Tremblay G, Bartels S, Weitbrecht K, Wormit A, Usadel B, Haughn G, Kermode AR. 2013. Demethylesterification of Cell Wall Pectins in Arabidopsis Plays a Role in Seed Germination. Plant Physiol, 161 (1): 305-316.

Murashige T, Skoog F. 1962. A revised medium for rapid growth and bio assays with tobacco tissue cultures. Physiol Plant 15 (3): 473-497.

Murthy HN, Lee E-J, Paek K-Y. 2014. Production of secondary metabolites from cell and organ cultures: strategies and approaches for biomass improvement and metabolite accumulation. Plant Cell Tiss Org Cult 118 (1): 1-16.

Nagata T, Takebe I. 1971. Plating of isolated tobacco mesophyll protoplasts on agar medium. Planta 99 (1): 12-20.

Naik PM, Manohar SH, Praveen N, Murthy HN. 2010. Effects of sucrose and $\mathrm{pH}$ levels on in vitro shoot regeneration from leaf explants of Bacopa monnieri and accumulation of bacoside A in regenerated shoots. Plant Cell Tiss Org Cult 100 (2): 235-239.

Paiva M, Janick J. 1982. In vivo and in vitro production of alkaloids in Theobroma cacao, L.

Pal R, Girhepunje K, Upadhayay A, Thirumoorthy N. 2012. Antioxidan and free radical scavenging activity of ethanolic extract of the root of Morinda citrifolia (Rubiaceae). Afr J Pharm Pharmacol 6 (5): 278282.

Pande A, Dosad S, Chawla HS, Arora S. 2015. In-vitro organogenesis and plant regeneration from seed-derived callus cultures of finger millet (Eleusine coracana). Braz. J Bot 38 (1): 19-23.

Perry CA, Leigh RA, Tomos AD, Wyse RE, Hall JL. 1987. The regulation of turgor pressure during sucrose mobilisation and salt accumulation by excised storage-root tissue of red beet. Planta, 170 (3): 353-361.

Phua QY, Chin CK, Asri ZRM, Lam DYA, Subramaniam S, Chew BL. 2016. The Callugenic Effects Of 2, 4-Dichlorophenoxy Acetic Acid (2, 4-D) On Leaf Explants Of Sabah Snake Grass (Clinacanthus nutans). Pak J Bot 48 (2): 561-566.

Prachayasittikul S, Buraparuangsang P, Worachartcheewan A, IsarankuraNa-Ayudhya C, Ruchirawat S, Prachayasittikul V. 2008. Antimicrobial and antioxidative activities of bioactive constituents from Hydnophytum formicarum Jack. Molecules 13 (4): 904-921.

Purnamaningsih R. 2016. Callus induction and regeneration optimation of four paddy varieties through in vitro culture. J AgroBiogen 2 (2): 7480. [Indonesian]
Radha RK, Shereena SR, Divya K, Krishnan PN, Seeni S. 2011. In vitro propagation of Rubia cordifolia Linn. A medicinal plant of the western ghats. Intl J Bot 7: 90-96.

Robbiani D, Nurhidayati T, Jadid N. 2010. The effect of Naphthalene Acetic Acid and Kinetin combination in tobacco (Nicotiana tabacum L.) leaves by in vitro culture. [Hon. Thesis]. Institut Teknologi Sepuluh November, Surabaya. [Indonesian]

Rout GR, Samantaray S, Das P. 2000. In vitro somatic embryogenesis from callus cultures of Cephaelis ipecacuanha A. Richard. Scientia Horticulturae 86 (1): 71-79.

Sanjaya RE, Tedjo YY, Kurniawan A, Ju Y-H, Ayucitra A, Ismadji S. 2014. Investigation on supercritical $\mathrm{CO} 2$ extraction of phenolicphytochemicals from an epiphytic plant tuber (Myrmecodia pendans). $\mathrm{J} \mathrm{CO}_{2}$ Utiliz 6: 26-33.

Sari YP, Kustiawan W, Sukartiningsih S, Ruchaemi A. 2017. The potential of secondary metabolites of Myrmecodia tuberosa from different host trees. Nusantara Biosci 9 (2): 170-174.

Sari YP, Kusuma R. 2015. Modification of sucrose concentration in solid and liquid medium for Myrmecodia tuberosa jack callus growth in vitro. Bio Wallacea Jurnal Ilmiah Ilmu Biologi 1 (1): 9-13. [Indonesian]

Shahnewaz S, Bari M. 2004. Callus Induction and plant regeneration in anther culture of rice (Oryza sativa L.). Plant Tiss Cult 14 (1): 37-43.

Shi D. 2014. Effects of culture media and plant growth regulators on micropropagation of Willow (Salix matsudana 'Golden Spiral) and Hzelnut (Corylus colurna 'Te Terra Red). [Thesis]. University of Nebraska, Nebraska, USA.

Smetanska I. 2008. Production of secondary metabolites using plant cell cultures. In: Food Biotechnology. Springer, Berlin.

Soeksmanto A, Subroto MA, Wijaya H, Simanjuntak P. 2010. Anticancer activity test for extracts of sarang semut plant (Myrmecodia pendens) to HeLa and MCM-Ba cells. Pak J Biol Sci 13: 148-151. [Indonesian]

Stella A, Braga MR. 2002. Callus and cell suspension cultures of Rudgea jasminoides, a tropical woody Rubiaceae. Plant Cell Tiss Org Cult 68 (3): 271-276.

Stobbe H, Schmitt U, Eckstein D, Dujesiefken D. 2002. Developmental stages and fine structure of surface callus formed after debarking of living lime trees (Tilia sp.). Ann Bot 89 (6): 773-782.

Subroto MA, Saputro H. 2008. Fight the disease with the ant nest plant. Penebar Swadaya, Jakarta. [Indonesian]

Sudiono J, Oka CT, Trisfilha P. 2015. The Scientific Base of Myrmecodia pendans as Herbal Remedies. Br J Med Med Res 8 (3): 230-237

Supriatno D. 2014. Antitumor activity of Papua's Myrmecodia pendans in human oral tongue squamous cell carcinoma cell line through induction of cyclin-dependent kinase inhibitor p27Kip1 and suppression of cyclin E. J Cancer Res Ther 2 (3): 48-53.

Tambe NM. 2013. Studies in in vitro callus culture of Solanum khasianum Clarke. Intl J Recent Trends Sci Tecnol 5 (3): 111-112.

Trejo-Tapia G, Jimenez-Aparicio A, Rodriguez-Monroy M, De JesusSanchez A, Gutierrez-Lopez G. 2001. Influence of cobalt and other microelements on the production of betalains and the growth of suspension cultures of Beta vulgaris. Plant Cell Tiss Org Cult 67 (1): 19-23.

Waes Jv, Debergh P. 1986. In vitro germination of some Western European orchids. Physiol Plant 67 (2): 253-261.

Welsh JR, Mogea JP. 1991. Basics of Genetics and Plant Breeding. Erlangga, Jakarta. [Indonesian]

Yu S, Kwok KH, Doran PM. 1996. Effect of sucrose, exogenous product concentration, and other culture conditions on growth and steroidal alkaloid production by Solanum aviculare hairy roots. Enzyme Microb Technol 18 (4): 238-243.

Zhang Y-H, Zhong J-j, Yu J-T. 1996. Enhancement of ginseng saponin production in suspension cultures of Panax notoginseng: manipulation of medium sucrose. J Biotechnol 51 (1): 49-56.

Zulfiqar B, Abbasi NA, Ahmad T, Hafiz IA. 2009. Effect of explant sources and different concentrations of plant growth regulators on in vitro shoot proliferation and rooting of avocado (Persea americana Mill.) cv.“Fuerte". Pak J Bot 41 (5): 2333-2346. 